PAP

25,1

50

Received 22 April 2021

Revised 28 December 2021 Accepted 16 January 2022

\section{Assessing fiscal health of local governments in Bangladesh: evidence from some south- western municipalities}

\author{
Tasnim Murad Mamun and Sajib Chowdhury \\ Economics Discipline, Khulna University, Khulna, Bangladesh
}

\begin{abstract}
Purpose - Status of fiscal health of local governments helps in determining planned budget and realistic action plan for citizens' wellbeing. This paper aims to assess the fiscal health of local governments in Bangladesh.

Design/methodology - Using data from 18 south-western municipalities of Bangladesh during the fiscal year 2018-19, this research measures fiscal health by applying Wang, Dennis and Tu's solvency test and Brown's Ten-Point Test.

Findings - The result shows that one-tenth of the entire municipalities are endowed with better position, whereas almost 39 percent of municipalities are in the worst situation and nearly 50 percent of municipalities are in the average category. Because of having limited liabilities, the municipalities are endowed with more than enough cash solvency and reasonable level of long-run solvency. The key problems are that budgetary solvency of all municipalities is not satisfactory, and service expenses are more than their revenue generation. This study suggests improving the financial capabilities of the municipalities through properly using their resources, generating loans, and claiming a need-based budget from the central government.

Originality - The paper investigates the status of fiscal solvency of local governments in Bangladesh in a new dimension. The findings might be helpful to policymakers in budgeting for development initiatives of local governments in Bangladesh so that citizens' better wellbeing is ensured.
\end{abstract}

Keywords Local government, Fiscal health, Wang, Dennis and Tu's solvency test, Brown's Ten-Point Test, Bangladesh

Paper type Research paper

\section{Introduction}

Measuring fiscal health is essential to determine the ability of a government since it helps to meet their financial obligation, a major challenging task for any government in a country (McDonald, 2018). Strengthening local administration is essential to meet up the financial obligation of the local governments, as it helps by mobilizing resources and services from central government to different levels of local governments (Mollah, 2007). Local government plays a vital role by providing services to their citizens e.g., they involve in the different development programs, work for poverty reduction (Lobao and Kraybill, 2009), mobilize local

(c) Tasnim Murad Mamun and Sajib Chowdhury. Published in Public Administration and Policy. Published by Emerald Publishing Limited. This article is published under the Creative Commons Attribution (CCBY 4.0) license. Anyone may reproduce, distribute, translate and create derivative works of this article (for both commercial and non-commercial purposes), subject to full attribution to the original publication and authors. The full terms of this license may be seen at http://creativecommons. org/licences/by/4.0/legalcode

The authors acknowledge the institutional support provided by Khulna University, Bangladesh. We would like to thank three students, Sharmin Akter Keya, Jannatul Naim Palash and Jayanta Biswas who helped with data collection, extraction and technical support. In addition, many thanks are due to the concerned municipal authorities. Finally, our thankful gratitude goes to the anonymous reviewers and editors for their invaluable comments and suggestions to improve this article.
Public Administration and Policy Vol. 25 No. 1,2022 pp. $50-63$

Emerald Publishing Limited 1727-2645

DOI 10.1108/PAP-04-2021-0027 
resources (Larson, 2002), enhance co-ordination, increase the flow of information and resource from top to bottom level, create responsiveness of the central government to ensure citizen's facilities and maintain the political stability (Siddiqi, 1995; Turley et al., 2015). More importantly, as a locally elected political sub-division of central governments, local government has substantial control over local affairs (Panday, 2011) and are supposed to collect revenue by imposing fees, taxes to provide the public services. Thus, it is inevitable to reveal how well the local governments are doing and how governments can strengthen their abilities to meet up the public demand. By using the fiscal health analysis of local governments in a country, we can easily explore the answer to these questions.

Without a healthy financial condition of local governments, public service quality will suffer in future (Huang and Ho, 2013). When there is an imbalance between the demand and supply of public service, this indicates that the financial condition of the government is in distress. Thus, it creates a problem between the citizens who want those public services and the officials of the local government who are accountable to ensure the provision of that services (Amrahova et al., 2017). This problem causes tension between these two parties (McDonald, 2018). Therefore, it is crucial to measure the fiscal health of local government to minimize this problem. Since municipalities are the best demonstrator of the local governments, stakeholders should prioritize a better understanding of the latter's financial capability through assessing the fiscal condition of the municipalities.

In recent times, increasing demand for public service makes it more difficult for a local government official to maintain this increasing demand with the available resources. More importantly, a recession or other financial breakdown may decline the revenue of the local government. As a result, the local government would face a financial deficit to conduct their services. Generally, government bodies with financial stress fail to meet their financial obligations. On the contrary, governments with low stress are well managed, and it is easier for them to maintain an adequate slack, solvent budget and to meet short-term and long-term budgets (Hendrick, 2004). Poor financial condition implies that local governments are less susceptible to maintain the current financial obligation at an acceptable level of available resources. Assessing the fiscal health of the local government helps the local government authorities to run their services according to the public demand. There are some other reasons behind the assessment of the fiscal health of local government. It influences the economic development, local government's organizational flexibility quality, competitiveness, service provision quality, variation in services, quality of the human resource, long-term creditworthiness, and local government cost on citizen's competitiveness. According to Honadle et al. (2003), assessing the local government's fiscal health helps to identify and solve different financial problems.

The officials of local government often face difficulty in choosing the appropriate measure of fiscal health. While measuring fiscal health, it is essential to emphasize the indicators such as economic and population change, revenue and expenditures per person, debt per person (Caperchione and Mussari, 2000). Hence, the main target of this study is to assess the fiscal health of local governments in Bangladesh. However, the authors conduct this analysis to focus on two measures - Wang, Dennis and Tu's solvency test and Brown's Ten-Point Test. Each of these approaches provides different indicators of a local government's financial condition. Brown's Ten-Point Test focuses on five financial dimensions (Table 1) with ten financial ratios. It has included revenue, expenditure, operating position, debt, and unfunded liabilities to measure the fiscal health condition of the local government. Similarly, Wang, Dennis and Tu's include cash solvency, budget solvency, service solvency, and long-run solvency with 11 indicators to determine the solvency of a local government (Table 2). By comparing these different indicators, the concerned authorities can easily understand the actual financial health of those local government bodies. 
PAP 25,1

\section{2}

Table 1.

Financial indicators of Brown's TenPoint Test

\begin{tabular}{ll}
\hline Type & Indicator \\
\hline Revenue & Total Revenue Per Capita \\
& \\
& Intergovernmental Revenues/ Total
\end{tabular}

Revenue Percentage

Property Tax or Own Source Tax

Revenues/Total Revenues Percentage

Expenditure Total Expenditure Per Capita

Operating Operating Surplus or Deficit/

Position Operating Revenue Percentage

General Fund Balance/ General Fund

Revenues Percentage

Enterprise Funds Working Capital

Coverage Percentage

Debt Long Term Debt/ Assess Value

Percentage

Debt Service/Operating Revenues

Percentage

Unfunded Postemployment Benefit Assets/

Liability Liabilities Percentage

Source: Maher and Nollenberger (2009).
Measurement

Total Revenues for all Governmental Funds (Excluding Capital Project Funds) Divided by Population

Intergovernmental Revenues for the General Fund Divided by Total General Fund Revenues

Total Tax Revenues Levied Locally for the General Fund Divided by Total General Fund Revenues

Total Expenditures for all Governmental Funds (Excluding Capital Project Funds) Divided by Population

General Fund Operating Surplus or Deficit

Divided by Total General Fund Revenues

General Fund Unreserved Fund Balance Divided by Total General Fund Revenues

Current Assets of Enterprise Funds Divided by

Current Liabilities of Enterprise Funds

Long Term General Obligation Debt/Total General

Fund Revenue

General Obligation Debt Service/Total General

Fund Revenue

Funded Ratio (i.e., Actuarial Value of Plan Assets/ Actuarial Accrued Liability)

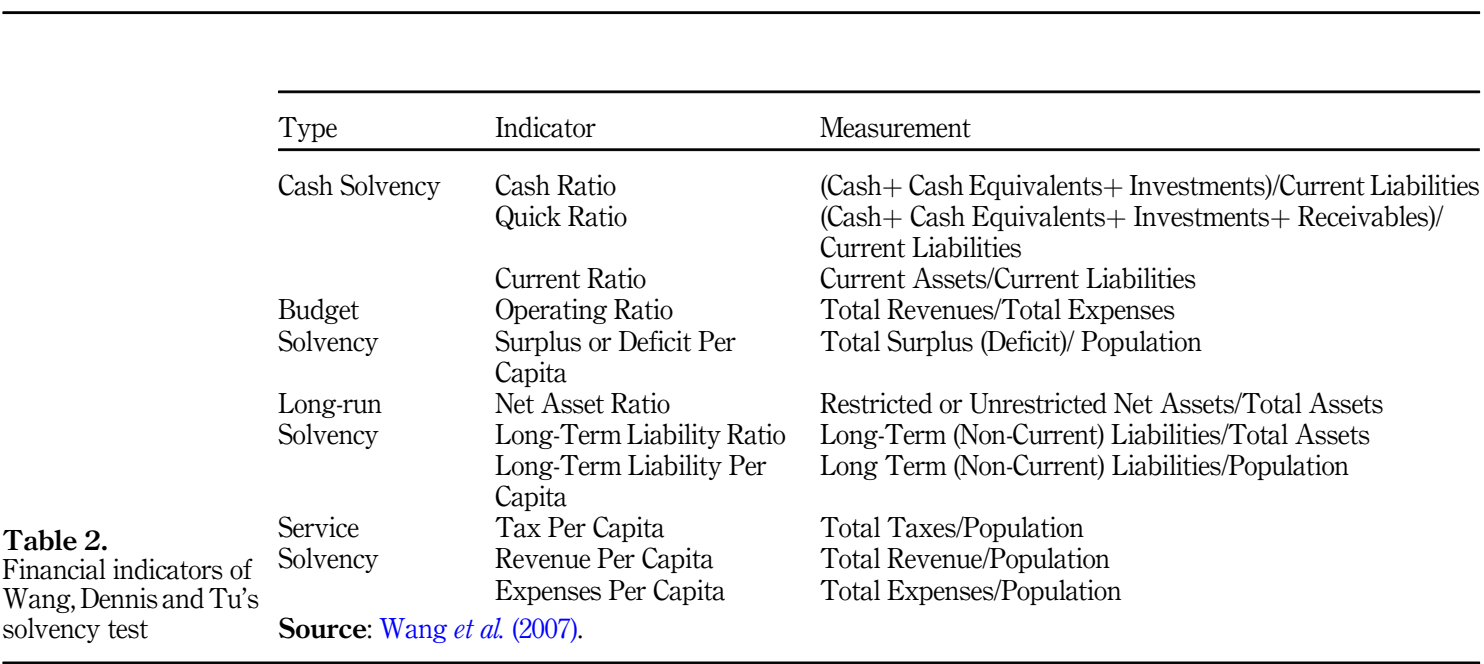

\section{Literature review}

The concept of "fiscal health" or "financial health" is somewhat abstract which cannot be directly observed and precisely measured (Bisogno et al., 2019). Generally speaking, fiscal health is the ability of a government to provide adequate public service to the citizens and satisfy different obligations. More specifically, fiscal health measures the financial performance of a government (Wang et al., 2007). Helpap (2016) and Maher and Nollenberger (2009) have insighted that fiscal health balances the government's financial obligation with its available revenue streams. Therefore, fiscal health indicates the 
proficiency of governments in how efficiently they can meet all types of financial obligation (immediate or short-term, long-term obligation) and the ability of the local government to finance the base-level programs and service as required by law (McDonald, 2018). According to Wang et al. (2007), the local government's fiscal health or financial condition is mainly the ability to timely meet its long-term and short-term financial obligation in the form of debt, services expenses, or expenditure. The governments can bear this obligation from either immediate or future financial resources (Hendrick, 2004). Different factors like economic performance, natural and demographic factors, administrative efficiency, revenue and expenditures per person, debt per person, decentralization of resources, types of service affect the fiscal health of local governments (Bastida et al., 2009; Trussel and Patrick, 2018). McDonald (2018) views the fiscal health of government by using four dimensions: government's ability to meet its immediate or short-term financial obligations, the ability to meet its long-term financial commitments, the ability to meet its financial obligations over a budgeted fiscal year, and the ability to finance its base level programs and services.

In Bangladesh, the structure of local government seems to be complex when compared to the international standard. It consists of multiple layers and divides into two categories, i.e., rural local government and urban local government. In rural areas, the layers of local governments are Upazila Parishad (sub-units of district-level local government), Union Parishad (most minor rural administrative units in Bangladesh), and Ward (a division of city and town for administrative purposes). Local government institutions in the urban area consist of Municipalities (Pourashava) and City Corporations. City corporations are the first level of urban local government, and municipalities are the second level. There are 12 city corporations and 327 municipalities across the country as of August 2019 (Rahman et al., 2019). The law mandates that all the layers of local governments provide a wide range of services in income generation, employment creation, sanitation facilities, water supply management, and regional infrastructure development (Kiewiet and McCubbins, 2014).

Generally, local government institutions in Bangladesh have their own sources of revenue. However, they can generate only a small portion of income relative to their needs and consequently always suffer from a shortage of funds. Local government can generate revenue by using two significant sources. One is tax revenue, which includes taxes on property, income, professions, trades, taxes on vehicles and animals, tax on cinema, drama and other entertainment, tolls, and minor surcharges like advertisement and marriage. Another source is non-tax revenue, including fees, charges, fines, rents, profits from the property, grants from governments, and receipts from charitable funds (Bhattacharya et al., 2013; Elias, 2006).

In the urban area, a significant portion of revenue comes from the central government's allotment. The central government is accountable for transferring annual block grants (supportive tiers for ensuring various local affairs) to local governments under the Annual Development Programme (ADP). The government's surplus revenue budget, domestic and external borrowing, and aid from donor agencies finance the ADP fund of the central government. However, the expenditure responsibilities of the local government in Bangladesh are very narrow relative to the duties that are performed by the local governments around the world (Fox and Menon, 2008). Local governments in Bangladesh have few responsibilities like some local development activities, ensuring facilities of community health, primary and secondary education, water supply management, and sewerage management. Some research findings state that the local governments of Bangladesh are less efficient and held poor records of public service delivery (Bhattacharya et al., 2013; Fox and Menon, 2008).

To understand fiscal health, researchers stepped forward to develop a set of approaches for measuring fiscal health (Kim et al., 2020; Maher and Nollenberger, 2009; Wang et al., 2007). For analysing the fiscal health of local government, Huang and Ho (2013) used quantile 
PAP

25,1

analysis; Bastida et al. (2009) used regression analysis; Hendrick (2004) used fiscal health indices measurement. In literature, the authors find two types of methodology to measure the fiscal health condition in both developed and developing countries municipalities: scale approach (Brown, 1993; Kleine et al., 2003) and disaggregated indicator approach (Honadle et al., 2003; Hendrick, 2004; Wang et al., 2007). This study uses both approaches to measure the fiscal health of local governments. Every method has some limitations, but those approaches have been used widely for measuring fiscal health (McDonald, 2018).

More importantly, many studies on fiscal health are available in the literature, but most of them are focused on the developed country's municipalities or other organizations. However, a specific study addressing the local government's fiscal health in Bangladesh using a combined framework of Wang, Dennis and Tu's Solvency test and Brown's Ten-Point Test is hardly available in the literature. Additionally, the selected methods efficiently help to check out the different indicators of local government that might be helpful for the policy-making decisions of the concerned stakeholders. Therefore, this research focuses on this crucial area of public economics.

\section{Methodology \\ Sample and data}

In Bangladesh, there are a total of 327 municipalities within eight divisional cities (Rahman et al., 2019). In this study, the authors mainly focus on the municipalities of the south-western region in Bangladesh which comprises of 32 municipalities. To attain explorative evidence on the determination of fiscal health on local government, the authors use the random sample of 18 municipalities among 32 municipalities of this region, i.e., Jashore, Noapara, Shailkupa, Kaliganj, Magura, Narail, Kalia, Mongla, Paikgacha, Satkhira, Kolaroa, Darshana, Kushtia, Kumarkhali, Meherpur, Bagherhat, Chuadanga and Benapole municipalities (Figure 1). The study covers about 56.25 percent of the municipalities of this region. Among the selected municipalities representation of both district and upazila level entities comprise almost 44 percent and 56 percent respectively. Thus, the sampled municipalities represent the general condition of local government in Bangladesh. Since, municipal data is not publicly available in Bangladesh, for measuring its fiscal health; data was extracted from archival documents like annual financial statement, annual budget book and other relevant sources of the selected municipalities during the fiscal year 2018-2019. For collecting data, the authors issued letter to the mayor of every municipality and requested them to assist by getting required data and other information. They responded cordially by providing their archival documents and helping to understand the actual financial scenario through arranging an interview to their assigned representative. Based on those collected data of the municipalities, the authors compile the relevant information on this research.

The research has relied upon data on four dimensions of solvency test in terms of cash, budget, long-run and service solvencies, and ten financial indicators of revenue, expenditure, operating finance, debt, and unfunded liability. Then, by formulating different variables from the collected data, the analysis is conducted by using Wang, Dennis and Tu's solvency test, and Brown's Ten-Point Test. Each of these approaches provides different indicators of a local government's financial condition. By comparing these different indicators, the study has tried to explore the overall actual financial health of those core local government institutions in Bangladesh.

\section{Brown's Ten-Point Test}

Brown's Ten-Point Test comprises a combination of ratio analysis which is a quantitative analysis of the local government's financial information that identifies the trends in financial behaviour or position and estimates the government's performance on whether it is 


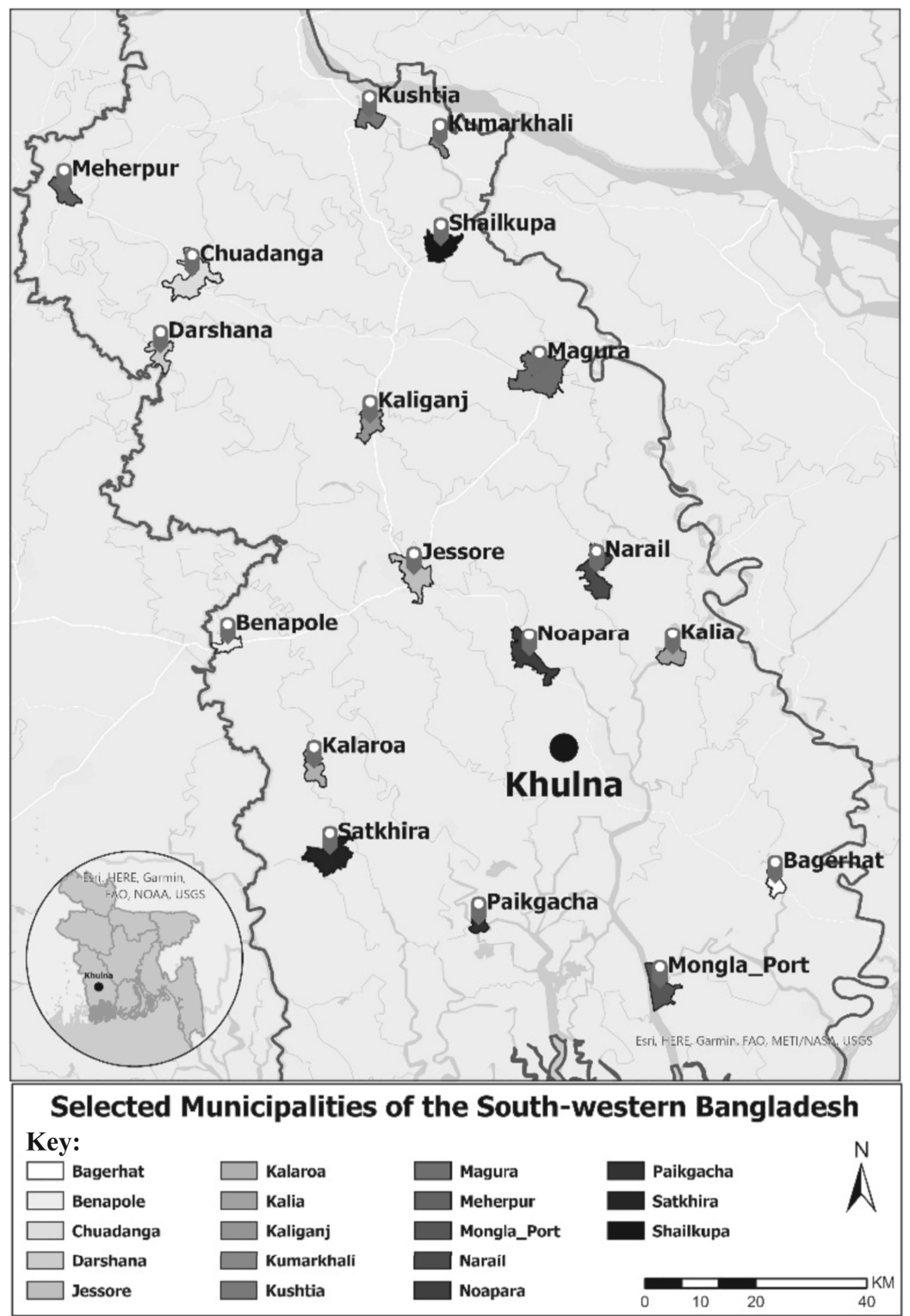

Source: By authors.
Fiscal health of local governments
Figure 1. Map of the surveyed municipalities in the south-west region of Bangladesh

improving or deteriorating. Additionally, it expresses the relationship as a percentage, rate, or proportion (McDonald, 2018). The ratio analysis method shows the relationship between financial statement accounts to identify an organization's financial state trends (Dance and Imade, 2019).

The straightforward application of ratio analysis has been considered as a popular method of analysing the financial condition, but this method has some limitations. 
PAP

25,1

The government choose and interpret only those ratios which generates favourable results to them. To overcome the problem arisen with ratio analysis, Brown's Ten-Point Test (1993) is applied which is both easy to use and understand. Ten financial ratios are captured in this method based on five dimensions, i.e., revenue, expenditure, operating position, debt, and unfunded liabilities. A brief description of the test indicators and their measurement system is in Table 1.

The ten ratios used in this method are easy to calculate and accessible by analysing a local government administrator's annual budget or report. This method helps a government recognize the point from which they differ from others and can respond to an interpretation of that position (McDonald, 2018). According to Brown (1993), the score of fiscal health varies between -10 and 20 . The result of " $\geq 10$ " represents "among the best", " $5-9$ " identifies "better than most", "1-4" depicts "about average", "(-4 to 0)" shows "worse than most" and " $\leq-5$ " reveals "among the worst".

However, the estimation focuses on the local government's general fund only, which ignores the more comprehensive financial performance. In this method, there is insufficient evidence to support the structure of the grading scheme. This measurement only compares whether the government is doing better than others rather than measuring the actual holistic feature of its fiscal health (McDonald, 2018).

\section{Wang, Dennis and Tu's solvency test}

Wang et al. (2007) have researched to establish a new method by which financial conditions can be easily realized and to address the difficulties of previous methods. To measure the fiscal health, the research moved away from measuring variables and argued that the appropriate approach to measuring fiscal health should directly measure its actual financial condition, such as financial solvency. The study breaks this solvency down into four dimensions: cash solvency, budget solvency, long-run solvency, and service solvency to estimate fiscal health. Table 2 represents an overview of these dimensions and their indicators.

Firstly, cash solvency refers to an organization's ability to generate sufficient financial resources to pay its current liabilities. It is measured by using three indicators, i.e., cash ratio, quick ratio, and current ratio. A more considerable value of this ratio indicates that many specific resources are available to cover current liabilities. Secondly, budgetary solvency refers to an organization's ability to generate sufficient revenues to fund its current or desired service levels. Two indicators are used to measure budget solvency - the operating ratio and surplus (deficit) per capita. A larger value for these ratios indicates higher level of budget solvency. The effect of existing long-term obligations on future resources is considered as the concept of long-term solvency. Three indicators - net asset ratio, long-term liability ratio, and long-term liabilities per capita are designed to measure a government's ability to pay existing long-term obligations. Finally, service solvency is used to measure an organization's ability to pay and sustain existing service levels. Three indicators- taxes per capita, revenues per capita, and expenses per capita are used to measure the service solvency of local government. A larger value indicates a lower level of service-level solvency (McDonald, 2018).

\section{Results and discussion}

Brown's Ten-Point Test

Brown's Ten-Point Test provides a specific result, indicating the fiscal condition of municipalities or other organizations. It includes ten financial ratios depending on five dimensions, i.e., revenue, expenditure, operating position, debt, and unfunded liabilities. More importantly, Brown (1993) has focused on these five dimensions of estimating financial 
condition by using most commonly used ratios. Maher and Deller (2011) have described the dimensions of the government's revenue, government expenditure, operating position, the level of debt accrued by the government, and its unfunded pension liabilities. Brown (1993) has also described an approach for indexing and comparability based on benchmarking that is performed by calculating the ratios individually for both the experiment of government and localities.

In this research, Figure 2 represents that according to the fiscal health status, approximately one-tenth of the entire municipalities are endowed with better position, whereas 39 percent of municipalities are in the worst situation and 50 percent of municipalities are in the average category. More importantly, it is found that municipalities in this region accrue limited liabilities, which indicates the municipalities mainly depend on their earnings and central government's budget. Additionally, the revenue stream, expenditure per capita, and post-employment benefit of the municipalities are not good enough; specially most of the municipalities with average and worse fiscal health face these problems.

\section{Wang, Dennis and Tu's solvency test}

The result of Wang, Dennis and Tu's solvency test is presented in Table 3. It shows the summary statistics of the eleven financial indicators, which help to check out the cash solvency, budget solvency, long-run solvency, and service solvency. Because of lacking

\section{Fiscal health of the municipalities}

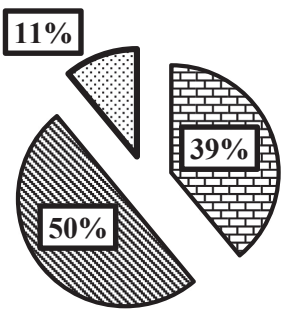

口Worse $\Delta$ Average $\mathbf{0 B e t t e r}$

Source: By authors.
Fiscal health of local governments

Figure 2. Status of municipalities based on Brown's TenPoint Test result

Table 3.

Summary statistics of Wang, Dennis and Tu's solvency test

\begin{tabular}{|c|c|c|c|c|c|c|}
\hline & $\mathrm{N}$ & Mean & Standard Deviation & Maximum & Minimum & \\
\hline Cash ratio & 18 & 196.10 & 394.45 & 1339.81 & 70.776 & \\
\hline Quick ratio & 18 & 201.89 & 401.55 & 401.55 & 70.77 & \\
\hline Current ratio & 18 & 6.78 & 21.90 & 93.36 & 1.77 & \\
\hline Operating ratio & 18 & 1.04 & 0.11 & 1.24 & 0.67 & \\
\hline Surplus (Deficit) per capita & 18 & 67.46 & 173.64 & 329.43 & -500.05 & \\
\hline Long term liability per capita & 18 & 932.97 & 1611.92 & 5532.04 & 41.43 & \\
\hline Tax per capita & 18 & 471.26 & 293.32 & 947.11 & 28.74 & \\
\hline Revenue per capita & 18 & 1745.07 & 1323.98 & 6152.13 & 699.58 & $\begin{array}{l}\text { 1able } 3 \text {. } \\
\text { Summary statistics of }\end{array}$ \\
\hline Expenses per capita & 18 & 1677.60 & 1263.41 & 5931.82 & 678.39 & Wang, Dennis and Tu's \\
\hline Source: By authors. & & & & & & solvency test \\
\hline
\end{tabular}


PAP

25,1

available data, the authors cannot calculate the net asset ratio and long-term liability ratio. Summary statistics of the indicators of Wang et al.'s solvency test, are represented in the following table.

\section{(1) Cash solvency}

Cash solvency includes three indicators, which are cash ratio, current ratio, and quick ratio.

The higher value of these three indicators indicates that the assets are available and the institutions are able to meet their current liabilities, therefore, a larger level of cash solvency is found in the selected municipalities. The cash ratio is calculated as the summation of the cash savings and cash equivalents in current assets over the current liabilities. The mean cash ratio is nearly 196.10 with a standard deviation of 394.45, shows a positive result because a higher value indicates higher level of financial ability. However, standard deviation shows a considerable variation within the municipalities, which indicates the inefficiency of some municipalities. The maximum cash ratio is found in Kushtia municipality, and the minimum cash ratio is found in Sathkhira municipality. The result reveals that local governments of the south-western part of Bangladesh are not equally solvent to lead the development initiative. A study by Wang et al. (2007) finds that the mean cash ratio for the municipalities of the USA is nearly 2.62, with a standard deviation of 5.74. Since Bangladeshi municipalities have too low current liabilities, this ratio is higher than municipalities of the USA.

The quick ratio (quick assets over current liabilities) is a more robust measure of liquidity than the current ratio. Quick assets refer to the liquid types of current assets, including cash and cash equivalents, marketable securities, and short-term receivables. A quick ratio, greater than one means that the municipality has enough quick assets to pay for its current liabilities. Quick assets (cash and cash equivalents, investments, receivables, and short-term receivables) are current assets that can be converted very easily into cash. Table 3 shows that the mean value of the quick ratio is approximately 201.89 with a standard deviation of 401.55, which is greater than one. Therefore, we can predict that the municipalities have enough quick assets to pay for their current liabilities. It is noticeable that because of low current liabilities, quick ratio gives a higher value. The average quick ratio in this analysis concludes that the current asset of the municipalities is enough to meet their limited liabilities.

The current ratio (current assets over current liabilities) shows how many times the institution can pay its current debt obligations based on its assets. "Current" usually means a short period of fewer than twelve months. The municipalities must have a current ratio of at least 1.0 to stay solvent, which can exactly meet their current debt obligations. Table 3 shows that the mean value of current ratios is nearly 6.78, indicates the municipalities have strong capacity to meet their current short-term debt obligations. This study finding is consistent with the findings of other research on Bangladesh and Indonesia (Alam et al., 2017; Ritonga et al., 2012).

In this study, the authors find that the current liabilities of these municipalities are too low. Even some municipalities have no borrowings or loans. On the other hand, cash, quick and current ratios are good enough, indicates the municipalities can meet their liabilities. In this sense, they have a scope to improve their overall condition by taking loans or other borrowings. Because of having high cash, current and quick ratio, these municipalities have a higher ability to reimburse the liabilities.

To check the correlation among three indicators of cash solvency, the authors use Karl Pearson's coefficient of correlation. It helps to prevent these three ratios' reliability from predicting cash solvency (Wang et al., 2007). Table 4 indicates the correlation among cash, quick and current ratio are highly associated with each other. All of them are positively correlated and statistically significant by $P<0.05$. 
Budget solvency includes two indicators (operating ratio and surplus (deficit) per capita) to measure financial health. Operating ratio $=$ total revenue over total expenses and surplus (deficit) per capita $=$ total surplus (deficit)/population are used to measure budget solvency. Higher budget solvency, which indicates a better condition, needs a larger value for this ratio. The mean of the operating ratio is nearly 1.04 with a standard deviation of 0.11 , indicating that municipalities can meet their expenses by their earnings though it varies across the municipalities. The maximum value indicates that some municipalities' total revenues are probably 124 percent more than their total expenses. Still, the minimum value shows that only 67.5 percent has the ability to meet their expenses by their revenue. The result of total surplus (deficit) per capita indicates that municipalities perform very differently in this measure. The average total surplus per capita is approximately BDT 67.46 (US\$0.79) with a standard deviation of BDT 173.64 (US\$2.05). The largest deficit per capita is nearly BDT500 (US\$ 5.90), and the largest surplus per capita is BDT 329.43 (US\$3.89). Here, BDT (Bangladeshi Taka) is converted into US\$ based on the exchange rate on 4 April 2021 (1BDT $=$ US\$0.012). Table 5 shows that the operating ratio and surplus per capita are highly associated and statistically significant by $p<0.05$. This result indicates that operating ratio and surplus per capita interdependently keep an impact on financial condition. Indonesian municipalities also maintain their budget solvency by generating adequate revenue to meet up their operational expenditure (Ritonga et al., 2012).

\section{(3) Long-run solvency}

Long-run solvency includes three indicators: net asset ratio, long-term liability ratio, and long-term liabilities per capita, for measuring a government's ability to pay existing longterm obligations. Clearly, a long-term liability ratio $=$ (long-term liabilities over total assets) or long-term liabilities per capita = (long-term liabilities/population) indicates long-run solvency. A larger ratio indicates a lower level of long-run solvency. The mean of long-run liabilities per capita is nearly BDT 932.99 (US\$11.02) with a standard deviation of BDT 1,611.92 (US\$19.04). It also represents that the current long-term liabilities per capita of the municipalities is well appreciated. The municipalities can raise the long-term liabilities by taking loans from other sources, might help to meet their financial obligations. Bhattacharya et al. (2013) find that the municipalities in Bangladesh can't raise the capital from capital market or borrow from other sources, through which they could be solvent in the long term.

\begin{tabular}{lccc}
\hline & Cash ratio & Quick ratio & Current ratio \\
\hline Cash ratio & 1.00 & & \\
Quick ratio & $0.99^{*}$ & 1.00 & \\
Current ratio & $0.66^{*}$ & $0.65^{*}$ & 1.00 \\
$* P<0.05$ & & &
\end{tabular}

Source: By authors.

Fiscal health of local governments

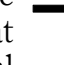


PAP

25,1

60

Net asset ratio and long-term liability ratio are not applicable because of lacking available data.

\section{(4) Service solvency}

Service solvency has three indicators, i.e., taxes per capita, revenue per capita, and expenses per capita. All of the ratios are very important to measure the financial condition. Taxes per capita $=$ taxes/population, revenue per capita $=$ total revenue/population and expenses per capita $=$ total expenses/population. Service solvency is important to measure service levels and municipalities' ability to pay. Taxes per capita and revenue per capita assess the tax burden and revenue burden, while expenditure per capita indicates the cost of services. Therefore, a larger value indicates a lower level of service solvency. This study estimates that per capita tax collected from inhabitants of concerned municipalities is approximately BDT 471.26 (US\$5.57) with a standard deviation of BDT 293.32 (US\$3.46). The mean of revenue per capita is nearly BDT 1,745.07 (US\$20.60) with a standard deviation of BDT 1,323.98 (US\$15.63). In addition, the mean of expenses per capita is approximately BDT 1,677.60 (US\$19.81), with a standard deviation of BDT 1263.41 (US $\$ 14.92$ ). It shows that people bear a higher tax though the service provided by the municipalities also charge high. However, this study exerts that the expenses per capita are less than the revenue per capita. This result is supported by the other research findings in Bangladesh (Alam et al., 2017; Bhattacharya et al., 2013).

The correlation among tax per capita, revenue per capita, expenses per capita are also described in Table 6. It shows that expenses per capita are highly associated with revenue per capita, which means change in revenue highly depends upon change in expenses. Revenue per capita and tax per capita are also moderately associated. All of them are positively correlated and statistically significant by $p<0.05$. Thus, it indicates that these ratios have a combined effect on service solvency.

Overall, this study identifies that the municipalities in this region are cash solvent, which indicates they can quickly meet up their current liabilities by using their resources. Therefore, they have enough scope to improve their overall condition by taking loans or other borrowings from bonds. Additionally, according to the results of budget solvency, municipalities can meet up their expenses by their earning though it varies from municipality to municipality. On the other hand, to ensure service level solvency, municipalities charge higher tax, and consequently the expense per capita becomes less than the revenue per capita.

\section{Conclusion}

To ensure sustainable cities and towns, one of the vital targets of SDGs, strengthening local government, mainly municipal governments, is inevitable in perspective of both financial capability and good governance. With the increasing force of urbanization, demand for public and utility services from municipalities is increasing day by day. Still, the local government in Bangladesh is not capable enough to raise additional revenue to meet the service commitments and obligations to urban dwellers. Besides, for accomplishing long-run development projects, i.e., sustainable river and canal management, sewerage system,

Table 6.
Correlation among per capita tax, revenue and expenses

\begin{tabular}{lccc}
\hline & Tax per capita & Revenue per capita & Expenses per capita \\
\hline Tax per capita & 1.00 & & \\
Revenue per capita & $0.63^{*}$ & 1.00 & 1.00 \\
Expenses per capita & $0.63^{*}$ & $0.99^{*}$ & \\
$* P<0.05$ & & & \\
Source: By authors. & & & \\
\hline
\end{tabular}


construction of roads, parks, markets, and other infrastructures, the local authorities are not contributing enough due to their fiscal deficiency, improper use of resources, and long term and lack of aid plans. However, before assessing whether the municipalities in Bangladesh are following their citizen charter appropriately, analysing fiscal health is the first and foremost factor. In Bangladesh, there are many types of research on different issues of local governments, i.e., decentralization, good governance, roles and contribution, and so on. Still, very little research is found on the exploration of fiscal conditions. From that obligation, this study tries to assess the financial status of municipalities in Bangladesh through analysis of several prominent approaches but under a combined framework and tries to suggest some associated policies by analysing extracted scenarios and existing literatures.

In this study, the authors adopt Brown's Ten-Point Test and Wang, Dennis and Tu's solvency test to measure the fiscal health by analysing the budget of the fiscal year 20182019 of around half of the south-western municipalities of Bangladesh. The results show that only about one-tenth of the municipalities are in better financial condition. In contrast, nearly half of the entire municipalities are average, and the others have worse fiscal conditions. Moreover, most of the municipalities with average and worse fiscal health face the inadequacy of revenue stream, expenditure per capita, and post-employment benefits. Another significant finding of the research is that these institutions have more than enough cash solvency and positive long-run solvency with reasonable long-run liabilities per capita for most municipalities due to limited external liability.

In the case of budget solvency, the average total surplus per capita is positive. Still, the variation denotes that some municipalities have a budget deficit to meet up their expenses. Most of the municipalities in Bangladesh aren't capable to generate adequate revenue to meet up their own expenses (Alam et al., 2017). In many cases, they depend on the central government's budget to meet their needs (Bhattacharya et al., 2013). This study suggests focus on the ratio of municipality's revenue stream and external liability. Since, their external liability is limited and they are cash solvent to meet it, they can quickly generate foreign and domestic loans to improve their financial capability and promptly meet their expenses.

However, in the perspective of service solvency, it is unexpectedly found that service expenses of the municipalities are more than their revenue generation. Behind this consequence, it is conceived that the municipal government levies household tax and cuts the handsome amount of service charge from the inhabitants. However, it is a prediction that the municipalities have a predilection for satisfying the routine work of the organization. Still, they have a massive opportunity of searching for external loans and aid for long-run development projects. This reluctance and preliminary plan keep them less capable, less efficient, and less obligated to use resources appropriately and aloof from properly maintaining citizen charter and strengthening this institution to ensure sustainable cities and towns. The authors suggest that the municipalities of Bangladesh should not be highly dependent on levying high service charges from urban dwellers; rather they have to utilize the opportunities to improve financial capabilities and be more dynamic local governments in properly using its resources, generating local and foreign loans, and claiming need-based budget from central government. Those strategies might help to increase the service level solvency as well as overall performance of the institutions (Ritonga et al., 2012).

Due to lack of intra-organisational and inter-organisational coordination among various departments of local governments, many projects are found incompletely implemented. Besides, central government's budgeting, planning and development focus are not coordinated with the local government's budget, participatory governance and accountability. Also, these facilities are not ensured by the authority, might cause the discrepancies in fiscal health of local governments (Panday and Panday, 2008).

The study would be more rigorous if sufficient data for every variable were available, and the prediction could be made with time-series data from similar developing countries. 
PAP

25,1

62

Besides, future investigation might be done by exploring the influence of financial conditions on some performance indicators of municipal governments. After all, this exploratory research might have a better role in taking policies regarding the financing of the local government of Bangladesh that will ultimately help to strengthen local governments to expedite the target for sustainable cities and towns. More importantly, this research suggests further research, discussion, and problem-solving applications by developing criteria to compare the fiscal condition, by revealing the associated factors of solvent fiscal health and by finding the relation between management practices and fiscal condition in the context of local governments in developing countries.

\section{References}

Alam, A.M., Alam, M. and Hoque, A. (2017), "Measuring financial condition of urban local government: a study of municipalities in Bangladesh", The Journal of Developing Areas, Vol. 51 No. 2, pp. 71-84.

Amrahova, K., Bluestone, P., Hildreth, B. and Larson, S.E. (2017), "An assessment of municipal fiscal health in the secondary municipal bond market”, working paper, Indiana University Applied Research in Public Finance Conference, Bloomington.

Bastida, F., Benito, B. and Guillaon, M.D. (2009), "An empirical assessment of the municipal financial situation in Spain”, International Public Management Journal, Vol. 12 No. 4, pp. 484-499.

Bhattacharya, D., Monem, M. and Rezbana, U.S. (2013), "Finance for local government in Bangladesh: an elusive agenda", working paper, CPD-CMI, Dhaka.

Bisogno, M., Cuadrado-Ballesteros, B., Santis, S. and Citro, F. (2019), "Budgetary solvency of Italian local governments: an assessment”, International Journal of Public Sector Management, Vol. 32 No. 2, pp. 122-141.

Brown, K.W. (1993), "The 10-Point Test of financial condition: toward an easy-to-use assessment tool for smaller cities", Government Finance Review, Vol. 9 No. 6, pp. 21-26.

Caperchione, E. and Mussari, R. (2000), Comparative Issues in Local Government Accounting, Kluwer Academic, Boston/Dordrecht/London.

Dance, M. and Imade, S. (2019), "Financial ratio analysis in predicting financial conditions distress in Indonesia stock exchange", Russian Journal of Agricultural and Socio-Economic Sciences, Vol. 86 No. 2, pp. 155-165.

Elias, S.A. (2006), "The political economy of decentralized governance: an assessment of rural local government reforms in Bangladesh", International Journal of Public Administration, Vol. 29 No. 13, pp. 1285-1309.

Fox, W.F. and Menon, B. (2008), "Decentralization in Bangladesh: change has been elusive", working paper, International Center for Public Policy, Andrew Young School of Policy Studies, Georgia State University, Atlanta.

Helpap, D.J. (2016), “The importance and complexity of assessing urban fiscal health”, State and Local Government Review, Vol. 48 No. 3, pp. 208-216.

Hendrick, R. (2004), "Assessing and measuring the fiscal heath of local governments: focus on Chicago suburban municipalities”, Urban Affairs Review, Vol. 40 No. 1, pp. 78-114.

Honadle, B.W., Cigler, B. and Costa, J.M. (2003), Fiscal Health for Local Governments, Elsevier Academic Press, Boston.

Huang, C.J. and Ho, Y.H. (2013), "Analyzing the fiscal health of local governments in Taiwan: evidence from quantile analysis", International Journal of Economics and Management Engineering, Vol. 7 No. 7, pp. 2068-2072.

Kiewiet, D.R. and McCubbins, M.D. (2014), "State and local government finance: the new fiscal ice age", Annual Review of Political Science, Vol. 17, pp. 105-122.

Kim, Y., Aldag, A.M. and Warner, M.E. (2020), "A balanced view: US local government managers' perceptions of fiscal stress”, Public Administration Quarterly, Vol. 44 No. 2, pp. 172-200. 
Kleine, R., Kloha, P. and Weissert, C.S. (2003). "Monitoring local government fiscal health: Michigan's Fiscal health of new 10-point scale of fiscal distress", Government Finance Review, Vol. 19 No. 3, pp. 18-24.

Larson, A.M. (2002), "Natural resources and decentralization in Nicaragua: are local governments up to the job?", World Development, Vol. 30 No. 1, pp. 17-31.

Lobao, L. and Kraybill, D. (2009), "Poverty and local governments: economic development and community service provision in an era of decentralization", Growth and Change, Vol. 40 No. 3, pp. $418-451$.

Maher, C.S. and Deller, S.C. (2011), "Measuring municipal fiscal condition: do objective measures of fiscal health relate to subjective measures?", Journal of Public Budgeting, Accounting \& Financial Management, Vol. 23 No. 3, pp. 427-450.

Maher, C.S. and Nollenberger, K. (2009), "Revisiting Kenneth Brown's 10-point test", Government Finance Review, Vol. 25 No. 5, pp. 61-66.

McDonald III, B.D. (2018), "Local governance and the issue of fiscal health", State and Local Government Review, Vol. 50 No. 1, pp. 46-55.

Mollah, M.A.H. (2007), "Administrative decentralization in Bangladesh: theory and practice", International Journal of Organization Theory \& Behavior, Vol. 10 No. 1, pp. 1-34.

Panday, P.K. and Panday, P.K. (2008), "The development of the urban government system in Bangladesh: does coordination exist?”, Local Government Studies, Vol. 34 No. 5, pp. 559-575.

Panday, P.K. (2011), "Local government system in Bangladesh: how far is it decentralised?", Lex Localis-Journal of Local Self-Government, Vol. 9 No. 3, pp. 205-230.

Rahman, M.S., Mohiuddin, H., Kafy, A.A., Sheel, P.K. and Di, L. (2019), "Classification of cities in Bangladesh based on remote sensing derived spatial characteristics", Journal of Urban Management, Vol. 8 No. 2, pp. 206-224.

Ritonga, I.T., Clark, C. and Wickremasinghe, G. (2012), "Assessing financial condition of local government in Indonesia: an exploration”, Public and Municipal Finance, Vol. 1 No. 2, pp. 37-50.

Siddiqi, K. (1995), Local Government in South Asia: A Comparative Study, University Press Ltd, Dhaka.

Trussel, J.M. and Patrick, P.A. (2018), "Assessing and ranking the financial risk of municipal governments: the case of Pennsylvania”, Journal of Applied Accounting Research, Vol. 19 No. 1, pp. 81-101.

Turley, G., Robbins, G. and McNena, S. (2015), "A framework to measure the financial performance of local government”, Local Government Studies, Vol. 41 No. 3, pp. 401-420.

Wang, X., Dennis, L. and Tu, Y.S. (2007), "Measuring financial condition: a study of US states", Public Budgeting and Finance, Vol. 27 No. 2, pp. 1-21.

\begin{abstract}
About the authors
Tasnim Murad Mamun by obtaining his bachelor's and master's in Economics from Khulna University is serving as an Assistant Professor of Economics at the same institution. He is motivated to do work in the field of applied microeconomics and public economics. Mr. Mamun has published several articles in peer-reviewed journals. He has also initiated and conducted several research projects. Before joining his current profession, he has gathered experience of working as an Assistant Director in Bangladesh Bank (the central bank of Bangladesh). Tasnim Murad Mamun is the corresponding author and can be contacted at: tmurad_08@econ.ku.ac.bd

Sajib Chowdhury is an undergraduate student of Economics Discipline at Khulna University, Bangladesh. He has experienced of working as a research assistant in several research projects. He is interested in the field of environmental economics, public economics, and development economics.
\end{abstract}

For instructions on how to order reprints of this article, please visit our website:

www.emeraldgrouppublishing.com/licensing/reprints.htm

Or contact us for further details: permissions@emeraldinsight.com 